\title{
Effect of Cryopreserved Cord Blood Serum on Reparative Processes in Rat Brain Tissue With Acute Focal Cerebral Ischemia
}

Реферат: У роботі досліджували можливість стимуляції репаративних процесів у щурів із гострою фокальною церебральною ішемією (ГФЦІ) введенням кріоконсервованої сироватки кордової крові людини (КСКК). Проведено порівняльний морфометричний аналіз структурних компонентів сенсомоторної ділянки кори головного мозку в динаміці лікування. Розвиток потужного нейротоксичного ефекту під час ГФЦІ був підтверджений якісними і кількісними показниками, зокрема зростанням у 4,57 рази альтераційного та у 3,62 рази перинейронального сателітного індексів по відношенню до контролю. Встановлено, що дегенеративні процеси супроводжуються потужними мікроциркуляторними змінами, пов'язаними з набряком мозкової тканини, про що свідчать збільшення середньої площі периваскулярних просторів у 45 разів відносно інтактних тварин і виражений вторинний спазм судин. Введення КСКК стимулювало репаративні процеси в перинекротичній зоні за рахунок підвищення щільності капілярів на 21,8\% порівняно з інтактними тваринами та попереджало розвиток дисфункції гематоенцефалічного бар'єра і мембрано-рецепторного комплексу нейронів. Показано, що КСКК мають позитивну дію при лікуванні пошкоджень мозку, спричинених ГФЦІ.

Ключові слова: гостра фокальна церебральна ішемія, некроз, репарація, кріоконсервована сироватка кордової крові.

Реферат: В работе исследовали возможность стимуляции репаративных процессов у крыс с острой фокальной церебральной ишемией (ОФЦИ) введением криоконсервированной сыворотки кордовой крови человека (КСКК). Проведен сравнительный морфометрический анализ структурных компонентов сенсомоторной области коры головного мозга в динамике лечения. Развитие мощного нейротоксического эффекта при ОФЦИ подтверждено качественными и количественными показателями, в частности ростом в 4,57 раза альтерационного и в 3,62 раза перинейронального сателлитного индексов по отношению к контролю. Установлено, что дегенеративные процессы сопровождаются мощными микроциркуляторными изменениями, связанными с отеком мозговой ткани, о чем свидетельствуют увеличение средней площади периваскулярных пространств в 45 раз относительно интактных животных и выраженный вторичный спазм сосудов. Введение КСКК стимулировало репаративные процессы в перинекротической зоне за счет повышения плотности капилляров на $21,8 \%$ по сравнению с интактными животными и предупреждало развитие дисфункции гематоэнцефалического барьера и мембранно-рецепторного комплекса нейронов. Показано, что КСКК оказывают позитивное влияние при лечении поражений мозга, вызванных ОФЦИ.

Ключевые слова: острая фокальная церебральная ишемия, некроз, репарация, криоконсервированная сыворотка кордовой крови.

Abstract: The research was performed to investigate the possibility of stimulating reparative processes in rats with acute focal cerebral ischemia (AFCl) by administration of human cryopreserved cord blood serum (CCBS). A comparative morphometric analysis of the structural components of the cerebral cortex sensor-motor area in dynamics of treatment was conducted. The development of a strong neurotoxic effect during $\mathrm{AFCl}$ was confirmed by qualitative and quantitative indices, in particular a 4.57 -fold in the alterational and in 3.62-fold incrresae in the perineural satellite indices relative to the control. Degenerative processes were accompanied with significant microcirculatory changes associated with swelling of brain tissue, as evidenced by a rise in average area of perivascular spaces by 45 times compared with intact animals and pronounced secondary spasm of the vessels.CCBS stimulated reparative processes in the perinecrotic zone due to an increase in the density of capillaries by $21.8 \%$ compared with intact animals and prevented the development of blood-brain barrier and neuronal membrane-receptor complex dysfunction. The CCBS has been shown to have a positive effect when tertaing the brain lesions caused by $\mathrm{AFCl}$.

Key words: acute focal cerebral ischemia, necrosis, reparation, cryopreserved cord blood serum.

\footnotetext{
${ }^{1}$ Медичний інститут Сумського державного університету

${ }^{2}$ Харківська медична академія післядипломної освіти

${ }^{3}$ Інститут проблем кріобіології і кріомедицини НАН України, м. Харків
}

${ }^{1}$ Medical Institute of Sumy State University

${ }^{2}$ Kharkiv Medical Academy of Post-Graduate Education

Institute for Problems of Cryobiology and Cryomedicine of the National Academy of Sciences of Ukraine, Kharkiv, Ukraine
*Автор, якому необхідно надсилати кореспонденцію: вул. Нова, 25, м. Суми, Україна 40019; тел.: (+380) 66-255-01-20 електронна пошта: volodlychko@gmail.com

Надійшла 21.08.2017

Прийнята до друку 03.09.2019
*To whom correspondence should be addressed:

25, Nova str., Sumy, Ukraine 40019;

tel.: +38066 2550120

e-mail: volodlychko@gmail.com

Received August, 21, 2017

Accepted September, 03, 2019

(C) 2019 V.S. Lychko, et al. Published by the Institute for Problems of Cryobiology and Cryomedicine

This is an Open Access article distributed under the terms of the Creative Commons Attribution License (http://creativecommons.org/licenses/by/4.0), which permits unrestricted reuse, distribution, and reproduction in any medium, provided the original work is properly cited. 
Гострі порушення мозкового кровообігу (ГПМК) $є$ однією з найчастіших причин захворюваності та смертності населення в усьому світі, а в структурі смертності вони поступаються тільки серцево-судинній патології. Серед усіх форм ГПМК суттєво переважає інфаркт головного мозку (ІГМ), на який припадає майже $70 \%$ випадків [9].

На сьогодні не доведено клінічну ефективність спазмолітиків, антиоксидантів, вітамінних комплексів, ноотропів, глюкокортикоїдів, нейропротекторів, які широко застосовуються в терапії неврологічних захворювань. У всьому світі та, зокрема, в Україні жодна із запропонованих методик лікування не здатна радикально вирішити проблему ефективного лікування ІГМ [14], тому важливим $є$ пошук принципово нових терапевтичних підходів. У цьому аспекті перспективними вважаються методи спрямованої тканинної регенерації, суть яких полягає в активації компенсаторних ресурсів пошкоджених клітин і тканин, стимуляції нейропластичності, яка має сприяти заміщенню пошкоджених структур і відновленню втрачених функцій $[8,11$, 26].

Використання факторів росту та біологічно активних речовин досить поширене у сучасній медицині. Вони застосовуються для лікування різних деструктивних процесів, які протікають в паренхіматозних органах (наприклад, цироз печінки), при імунодефіцитних станах, порушенні гемопоезу, безплідді, артропатіях тощо $[2,6]$. У межах такої терапії хворий отримує біологічно активні сполуки природного походження, які здатні впливати на різні ланки метаболізму та стимулювати репаративні процеси. Але даних щодо використання факторів росту та біологічно активних речовин, зокрема раннього онтогенезу, які можуть стимулювати репаративні процеси за умов гострої фокальної церебральної ішемії (ГФЦІ), на сьогоднішній день недостатньо.

В Україні препаратом, що містить біологічно активні речовини раннього онтогенезу, є «Кріокорд» - кріоконсервована сироватка кордової крові (КСКК). Цей препарат розроблено в Інституті проблем кріобіології і кріомедицини НАН України й дозволено Міністерством охорони здоров'я для клінічного використання.

Мета дослідження - вивчення морфологічних змін тканин головного мозку щурів в умовах експериментальної гострої фокальної церебральної ішемії в динаміці лікування кріоконсервованою сироваткою кордової крові для оцінки її нейрорепаративних властивостей.
Acute cerebovascular acident (CVA) are one of the most common causes of morbidity and mortality worldwide, and in the mortality structure they are second only to cardiovascular pathology. Among all forms of acute CVA, the ischemic stroke (IS), which accounts for almost $70 \%$ of cases [2], is strongly prevalent.

To date, the clinical efficiency of antispasmodic drugs, antioxidants, vitamin complexes, nootropics, glucocorticoids, neuroprotecting agents, which are widely used in treatment of neurological diseases, has not been proven. All over the world, and in Ukraine in particular, none of the proposed treatment modalities could drastically solve the problem of effective treatment of IS [9], so it is important to find the fundamentally new therapeutic approaches. In this aspect, the methods of targeted tissue regeneration, the essence of those is to activate the compensatory resources of the injured cells and tissues, to stimulate neuroplasticity, which should promote the replacement of damaged structures and restore the lost functions, are considered promising $[1,4,24]$.

Using the growth factors and biologically active substances is quite commonin contemporary medicine. They are applied for the treatment of various destructive processes occurring in parenchymatous organs (e. g., in liver cirrhosis), in immunodeficiency states, disorders of hematopoiesis, infertility, arthropathy etc. $[25,26]$. Within the framework of such a therapy, a patient receives biologically active compounds of natural origin, which are capable of influencing different metabolic links and stimulating reparative processes. However, the data on using the growth factors and biologically active substances, of early ontogenesis in particular, capable of stimulating the reparative processes in acute focal cerebral ischemia (AFCI), are currently insufficient.

In Ukraine, the product containing biologically active substances of early ontogenesis is 'Cryocord', i. e. cryopreserved cord blood serum (CCBS). This product was developed at the Institute for Problems of Cryobiology and Cryomedicine of the NAS of Ukraine and approved by the Ministry of Health Care of Ukraine for clinical use.

The purpose of this research was to study morphological changes of brain tissues of rats in the conditions of experimental AFCI in dynamics of treatment with cryopreserved cord blood serum to evaluate its neuroreparative properties.

\section{Materials and methods}

The study was performed in 60 outbred white Wistar male rats weighing $200 \pm 20$ g. The animals were housed in the animals facility and received 


\section{Матеріали та методи}

Дослідження було проведено на 60 безпорідних білих щурах-самцях лінії Вістар масою $200 \pm 20$ г. Тварини перебували в умовах віварію, отримували звичайний добовий раціон харчування і мали вільний доступ до води. Експерименти виконували відповідно до Закону України «Про захист тварин від жорстокого поводження» (№ 3447-IV від 21.02.2006 р.) із дотриманням вимог Комітету 3 біоетики Медичного інституту Сумського державного університету, узгоджених із положеннями «Свропейської конвенції $з$ захисту хребетних тварин, які використовуються в експериментальних та інших наукових цілях» (Страсбург, 1986).

Усіх тварин було розділено на три групи $(n=20$ у кожній): 1 (контроль) - інтактні щури без травматизації та лікування; 2 - тварини після моделювання ГФЦІ без лікування; 3 - щури після моделювання ГФЦІ, яким вводили препарат «Кріокорд» (КСКК).

Моделювання ГФЦІ здійснювали шляхом ін'єкції 0,1-0,3 мл суспензії сульфату барію («Істок-Плюс», Україна) в стерильному 0,9\%-му фізіологічному розчині в пропорції 1:3 у праву сонну артерію через розріз м'яких тканин на шиї [3].

Виходячи 3 того, що лікування хворих із ІГМ починається через 10-12 годин після прояву перших симптомів [17], препарат КСКК уводили через 12 годин 3 моменту моделювання ГФЦІ. Зважаючи на те, що перицелюлярний набряк досягає максимуму на 3-7-му добу, а явища вторинного ангіогенезу спостерігаються вже на 3-4-ту добу $[10,19]$, наступні введення препарату КСКК проводили на 2, 3 та 4-ту добу з моменту моделювання ГФЦІ. Препарат КСКК вводили внутрішньочеревно по 0,1 мл/кг. Дозу препарату розраховували за коефіцієнтами активності метаболізму [5].

Матеріал для морфологічного дослідження забирали після введення препарату КСКК тваринам із моделлю ГФЦІ через 7 діб від початку експерименту. Усі оперативні втручання проводили під внутрішньочеревним тіопенталовим наркозом. («Корпорація Артеріум», Україна) із розрахунку 20 мг на 1 кг маси тварини.

Для морфологічних досліджень тканину мозку експериментальних тварин фіксували шляхом транскардіальної перфузії сумішшю 4\%-го розчину параформальдегіду («Фармхім», Україна), 1\%-го розчину глютарового альдегіду («BASF», Hiмеччина), 5\%-го розчину сахарози («Compri Zucker», Німеччина) на 0,1M фосфатному буфері $(\mathrm{pH} 7,4)$ протягом 15-20 хв під тиском 90 мм рт. ст. a normal daily diet and had free access to water. The experiments were carried out in accordance with the Law of Ukraine 'On the Protection of Animals from Cruelty' (№ 3447-IV of 21.02.2006) in compliance with requirements of the Committee of Bioethics of the Sumy State University Medical Institute, as well as in accordance with the provisions of the 'European Convention for the Protection of Vertebrate Animals Used in Experimental and Other Scientific Purposes' (Strasbourg, 1986).

All animals were divided into three groups $(n=20$ in each): 1 (control) - intact rats without trauma and treatment; 2 - animals after modeling AFCI without treatment; 3 - rats after modeling AFCI, administered with the «Cryocord» (CCBS).

The AFCI was simulated by injection of $0.1-$ $0.3 \mathrm{ml}$ suspension of barium sulfate (JSC Istok-Plus, Ukraine) in a sterile $0.9 \%$ physiological solution in a $1: 3$ ratio into right carotid artery through an incision of soft tissues around the neck [16].

Assuming that the treatment of patients with IS begins 10-12 hours after emerging of the first symptom [12], the CCBS was administered 12 hours after the AFCI modeling. Due to the fact that pericellular edema reaches a maximum in 3-7 days, and the secondary angiogenesis phenomena are observed as early within 3-4 days [3,14], the subsequent injections of the CCBS were performed on days 2, 3 and 4 since the AFCI modeling. The CCBS was intraperitoneally administered at $0.1 \mathrm{ml} / \mathrm{kg}$. The dose of the drug was calculated by metabolism activity coefficients [23].

The material for morphological study was collected after the CCBS introduction to the animals with modeled AFCI after 7 days starting from beginning of the experiment. All the surgeries were performed under intraperitoneal thiopental anesthesia (Arterium Corporation, Ukraine) at the rate of $20 \mathrm{mg}$ per $1 \mathrm{~kg}$ of animal weight.

For morphological studies, the brain tissue of experimental animals was fixed via transcardial perfusion with a mixture of $4 \%$ paraformaldehyde solution (Pharmhim Ltd, Ukraine), 1\% glutaraldehyde solution (BASF, Germany), 5\% sucrose solution (Compri Zucker, Germany) with $0.1 \mathrm{M}$ phosphate buffer ( $\mathrm{pH}$ 7.4) for 15-20 min under a $90 \mathrm{~mm} \mathrm{Hg}$ pressure. After fixation of the material the light optical (paraffin) and electron microscopic specimens were prepared.

For electron microscopic examination, the sensory-motor area (SMA) of the cerebral cortex (Fpa and Fpp fields) were isolated according to the stereotaxic atlas of the adult rat brain [5]. Ultra-thin $(70-100 \mu \mathrm{m})$ sections of all layers of cortex SMA 
Після фіксації матеріалу готували світлооптичні (парафінові) і електронно-мікроскопічні препарати.

Для електронно-мікроскопічного дослідження виділяли сенсомоторну ділянку (СМД) кори головного мозку (поля Fpa i Fpp) за стереотаксичним атласом мозку дорослого щура [1]. Використовували ультратонкі (70-100 нм) зрізи всіх шарів СМД кори. Ультраструктуру зрізів досліджували за допомогою електронного мікроскопа «ПЕМ-125К» («SELMI», Україна) 3 прискорюючою напругою 75 кВ, який забезпечений системою зйомки і аналізу зображення «СAI-01A» («SELMI») на основі CCD-камери DX-2 і пакета програм («КАРРА», Німеччина).

Для гістологічних досліджень СМД кору головного мозку тварин фіксували у $10 \%$-му розчині формаліну. Далі зразки заливали в парафін і на мікротомі «RM2125 RTS» («Leica», Німеччина) готували зрізи товщиною 6-7 мкм, які потім забарвлювали гематоксиліном та еозином і аналізували на оптичному мікроскопі «Optica B-382PLiALC» («Bino Infinity Autolight», Італія). Мікрофотографування мікроскопічних зображень здійснювали цифровим фотоапаратом «Cool Pix 4500» («Nikon», Японія). Фотознімки обробляли за допомогою програми «Nikon View 5» («Nikon»).

Морфометричну оцінку зрізів проводили за допомогою програми «AxioVision» («Carl Zeiss», Німеччина). У III шарі СМД кори підраховували кількість нормальних та змінених (гіпер- і гіпохромних, 3 набряком, вакуолізованих, змінений стан ядер та нейроплазми) нейронів; описували комплекс нейрон-глія-капіляр; визначали індекс альтерації (співвідношення змінених нейронів до інтактних клітин), гліонейрональний індекс (співвідношення кількості гліальних елементів і нейронів), перинейрональний сателітний індекс (кількість сателітної глії на один нейрон), а також площу периваскулярних і перицелюлярних вільних просторів. Визначали діаметр і площу ядра ендотеліоцитів, гліальних клітин, товщину стінки, розмір просвіту церебральних капілярів і цитоплазматичної та базальної мембран, кількість мітохондрій, рибосом і полісом.

Для визначення динаміки змін вищезазначених морфометричних параметрів тканини мозку у кожної тварини порівнювали аналогічні ділянки мозку на боці модельованої ГФЦІ та інтактної гемісфери.

Статистичний аналіз проводили з використанням програми «Statistica 6.0» («StatSoft Inc.», США). Статистичну значущість оцінювали за U-тестом Манна-Уїтні з корекцією Бонферроні. Значення $p<0,05$ вважали статистично значущими. were used. The ultrastructure of the sections was examined using an electron microscope 'PEM-125K' (SELMI, Ukraine) with an accelerating voltage of $75 \mathrm{kV}$, which is equipped with a system of image capture and analysis 'SAI-01A' (SELMI) on the basis of CCD-camera DX-2 and the software (KAPPA, Germany).

For histological studies the SMA of cerebral cortex of animals was fixed with $10 \%$ formalin solution. Further, the samples were embedded in paraffin and the 6-7 $\mu \mathrm{m}$ thick sections were prepared with RM2125 RTS microtome (Leica, Germany), later they were stained with hematoxylin and eosin and analyzed with Optica B-382PLi-ALC optical microscope (Bino Infinity Autolight, Italy). Microphotography of the microscopic images was carried out with a digital camera 'Cool Pix 4500' (Nikon, Japan). Photographs were processed using Nikon View 5 (Nikon).

The slices were morphometrically evaluated using the AxioVision software (Carl Zeiss, Germany). In the third layer of the cortex SMA, the number of normal and altered (hyper- and hypochromic, with edema, vacuolated, altered state of nuclei and neuroplasm) neurons was calculated, the neuronglia-capillary complex was described, and the alteration index (ratio of altered neurons to intact cells), glioneuronal index (ratio of number of glial elements and neurons), perineuronal satellite index (number of satellite glia per neuron), and the area of perivascular and pericellular free spaces wer determined. The diameter and area of nucleus of endothelial cells (ECs), glial cells, wall thickness, the size of the lumen of cerebral capillaries and cytoplasmic and basal membranes, the number of mitochondria, ribosomes and polysomes were examined.

To determine the dynamics of changes in the above-mentioned morphometric parameters of brain tissue for each animal that were compared with similar areas of brain on the side of the simulated AFCI and intact hemisphere.

Statistical analysis was performed using Statistica 6.0 (StatSoft Inc., USA). Statistical significance was assessed by the Mann-Whitney U-test with Bonferroni correction. $\mathrm{P}$ values $<0.05$ were considered statistically significant.

\section{Results and Discussion}

During histological examination, 24 hours after the experiment start in an ischemic hemisphere of experimental animals of groups 2 and 3, unlike group 1, the cerebral capillaries of the cortex SMA showed occasional congestion (plethora and stasis), a pronounced swelling of the cerebral capillary wall 


\section{Результати та обговорення}

Під час гістологічного дослідження через 24 години після початку експерименту в ішемізованій півкулі головного мозку експериментальних тварин груп 2 і 3 на відміну від групи 1 у церебральних капілярах СМД кори місцями були виявлені застійні явища (повнокров'я та стаз), та виражене набухання стінки церебральних капілярів. У обстежених ділянках мозку у цілому зберігалися чіткість і вертикальне упорядкування шарів нейронів. Простежувалися периваскулярний і перицелюлярний (більш виражений у зонах поблизу капілярів) типи набряку. Частина капілярів мозку була спазмованою (рис. 1).

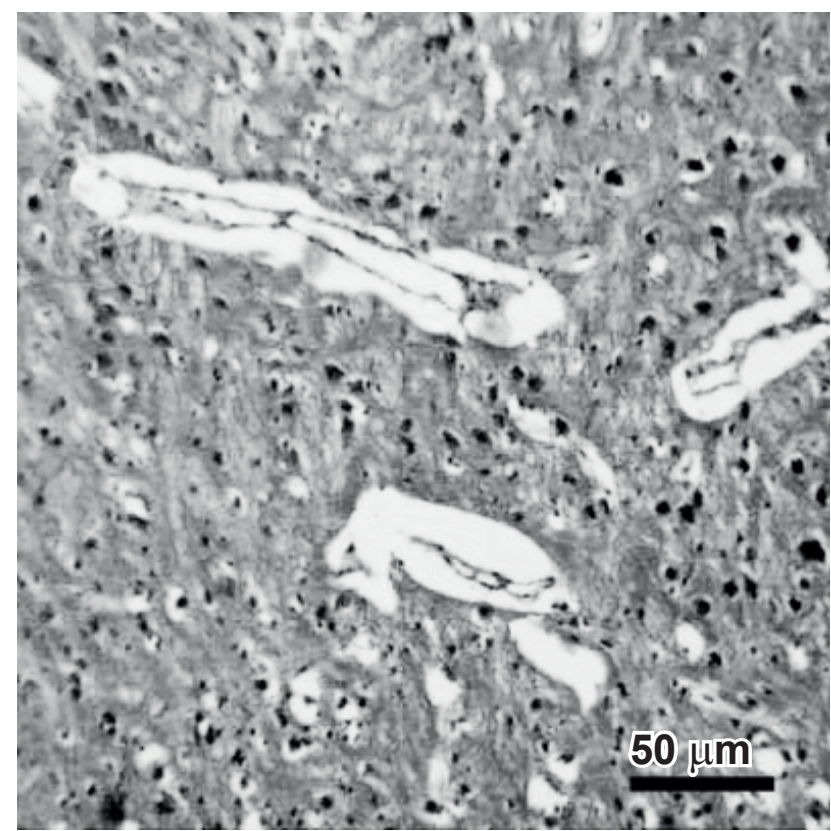

Рис. 1. Мікрофотографія капілярів шару III СМД кори головного мозку білого щура контрольної групи 2 на 4-ту добу після ГФЦІ. Забарвлення гематоксиліном і еозином.

Fig. 1. Microphoto of capillaries of the third layer of the cortex SMA of white rat of the control group 2 to day 4 after $\mathrm{AFCl}$. Hematoxylin and eosin staining.

Через 72 години і на 7-му добу з моменту моделювання ГФЦІ у тварин груп 2 і 3 в ішемізованій півкулі головного мозку також відзначалися мікроциркуляторні та дистрофічні зміни, які були більш вираженими у тварин групи 2: дилатація церебральних судин, дискомплексація та потовщення шарів судинної стінки, периваскулярний та перицелюлярний набряки (рис. 2).

Електронно-мікроскопічне дослідження тканини мозку тварин групи 2 через 4 доби після моделювання ГФЦІ порівняно з групою 1 виявило нерівномірність товщини і складчастість поверхні ендотеліоцитів, ймовірно, внаслідок їх пошкод- was also observed. In the examined areas of brain a clear and vertical ordering of layers of neurons was kept as a whole. Perivascular and pericellular (more pronounced in the areas near capillaries) types of edema were observed. Some brain capillaries were spastic (Fig. 1).

In 72 hours and on day 7 from the moment of AFCI simulation in the animals of groups 2 and 3, microcirculatory and dystrophic changes were also observed in an ischemic brain hemisphere, which were more pronounced in the animals of group 2, that is the cerebral vessel dilatation, discomplexation and thickening of vascular layers, perivascular and pericellular edema were found (Fig. 2).

Electron microscopic examination of brain tissue of group 2 animals in 4 days after the AFCI simulation in group 1 revealed uneven thickness and folding of a surface of ECs, likely as a result of their damage and reduced turgor (Fig. 2). This disclosed a plasma leakage with homogenization and the capillary wall vacuolation. In the endothelium lining the vessels' lumen, micro-growths and arc-shaped elements, formed as a result of its local detachment were determined (Figs. 2, 3).

Electron microscopic examination of SMA specimens of rats of group 3 on day 7 after the AFCI modeling revealed a decrease in perivascular edema of brain substance (Fig. 4), which testified to the regression of pathological changes on the side, where AFCI was simulated. However, the zones of enlightenment and expansion of the perivascular space were not determined, the surrounding celltissue structures were tightly adjacent to the wall of capillaries.

Comparative analysis of morphological status of the blood-brain barrier (BBB) elements of animals of groups 2 and 3 demonstrated that it corresponded to the norm after the CCBS administration (Fig. 5).

In addition, the disordered hemostasis during the development of changes in an ischemic region of brain was structurally manifested at all levels of capillary network of the cortex SMA. In this case, the changes were observed in all the layers of capillary wall, as well as in pericytes and vascular feet of astroglia. Changes in light-type ECs, swelling and destruction of mitochondria, cytoplasmic vacuoles, the appearance of large number of endocytotic vesicles, adhesion of erythrocytes to their surface, edema of pre-vascular processes of astrocytes were observed (see Fig. 2).

In rats of group 2 if compared to group 1 on day 7 after the AFCI modeling we observed the signs of reactive changes of ECs, namely an increased thickness and microclasmatosis, reduction of 
ження та зниження тургору (рис. 2). При цьому виявлялося плазматичне просочування 3 гомогенізацією та вакуолізацією стінки капіляра. В ендотелії, що вистилає просвіт судин, визначалися мікровирости й аркадоподібні елементи, які утворилися в результаті його локального відшарування (рис. 2, 3).

Електронно-мікроскопічне дослідження препаратів СМД кори щурів групи 3 на 7-му добу після моделювання ГФЦ встановило зменшення периваскулярного набряку мозкової речовини (рис. 4), що свідчило про регрес патологічних змін на боці модельованої ГФЦ. При цьому зони просвітлення і розширення периваскулярного простору не визначалися, навколишні клітинно-тканинні структури щільно прилягали до стінки капілярів.

Порівняльний аналіз морфологічного стану складових гематоенцефалічного бар'єра (ГЕБ) тварин груп 2 і 3 виявив, що після введення препарату КСКК вони відповідали нормі (рис. 5).

Крім того, порушення гемостазу в період розвитку змін в ішемізованій ділянці мозку структурно виявлялося на всіх рівнях капілярної мережі СМД кори. При цьому зміни відзначалися у всіх шарах стінки капілярів, а також у перицитах і судинних ніжках астроглії. Відмічалися зміна ендотеліальних клітин (ЕК) за світлим типом, набухання і деструкція мітохондрій, вакуолізація цитоплазми, велика кількість ендоцитозних бульбашок, адгезія еритроцитів до поверхні EK, набряк периваскулярних відростків астроцитів (див. рис. 2).

У щурів групи 2 порівняно 3 групою 1 на 7-му добу після моделювання ГФЦІ спостерігалися ознаки реактивних змін ЕК: збільшення товщини і мікроклазматоз, редукція міжклітинних зв'язків, розриви щілиноподібних контактів, часткова деструкція базальної мембрани (БМ), мітохондрій i полірибосомальних розеток, поява довгих цитоплазматичних відростків, набухання варикозних утворень ендотелію, розпорошення рибосом та відділення їх від мембрани гранулярного ендоплазматичного ретикулуму, агрегація еритроцитів, скупчення ліпідів у цитоплазмі перицитів (див. рис. 3).

Усі вищеописані зміни свідчили про розвиток гострої ендотеліальної дисфункції, що супроводжується значним підвищенням агрегаційних властивостей клітин крові та виділенням у системний кровотік різних біологічно активних речовин. Зазвичай, при цьому втрачається ізолююча функція ЕК, оголюються субендотеліальний шар і колагенові волокна БМ, відбувається відшарування клітин. Описані зміни призводять

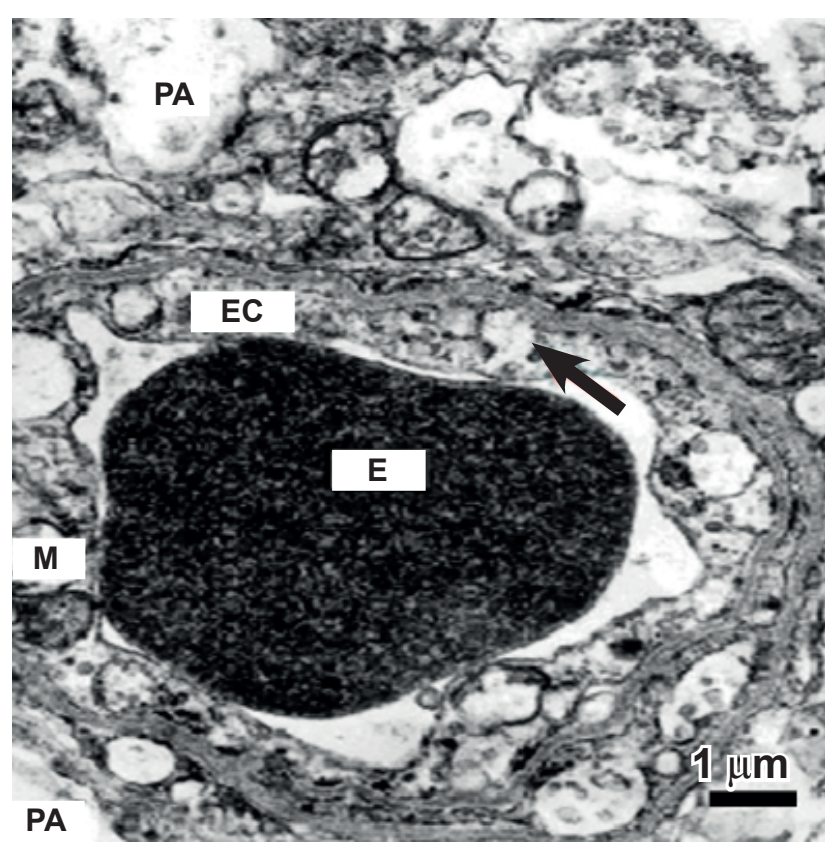

Рис. 2. Мікрофротографія церебрального капіляра шару III СМД кори головного мозку білого щура контрольної групи 2 на 4-ту добу після ГФЦІ. ЕС - ендотеліальні клітини; М - мітохондрії, ендоцитозні пухирці (стрілка); E - еритроцит; РА - периваскулярні відростки астроцитів.

Fig. 2. Microphoto of capillary of the third layer of the cortex SMA of white rat control group 2 on day 4 after $\mathrm{AFCl}$. EC - endothelial cells; $\mathrm{M}$ - mitochondria, endocytotic vesicles (black arrows); E - erythrocyte; PA - perivascular processes of astrocytes.

cell-to-cell contacts, ruptures of slit-like contacts, partial destruction of the basement membrane (BM), mitochondria and polyribosomal rosettes, appearance of long cytoplasmic processes, swelling of varicose endothelium formations, ribosome diffusion and separation from the membrane of granular endoplasmic reticulum, erythrocyte aggregation, lipid accumulation in cytoplasm of pericytes (see. Fig. 3).

All of the above changes indicate the development of acute endothelial dysfunction, which was accompanied with a sharp increase in aggregation properties of blood cells and are released into systemic circulation of various biologically active substances. Usually, herewith the ECs isolating function is lost, the subendothelial layer and collagen fibers of BM are denuded, and the cells are detached. The changes described lead to an activation of the Hageman factor, alterations in charge and zeta potential [22].

Destructive changes in cerebral capillaries are combined with powerful stimulation of intact ECs, resulting in an increased production of both vasodilators and vasoconstrictors. Enhanced vascular permeability of cerebral capillaries is accompanied 


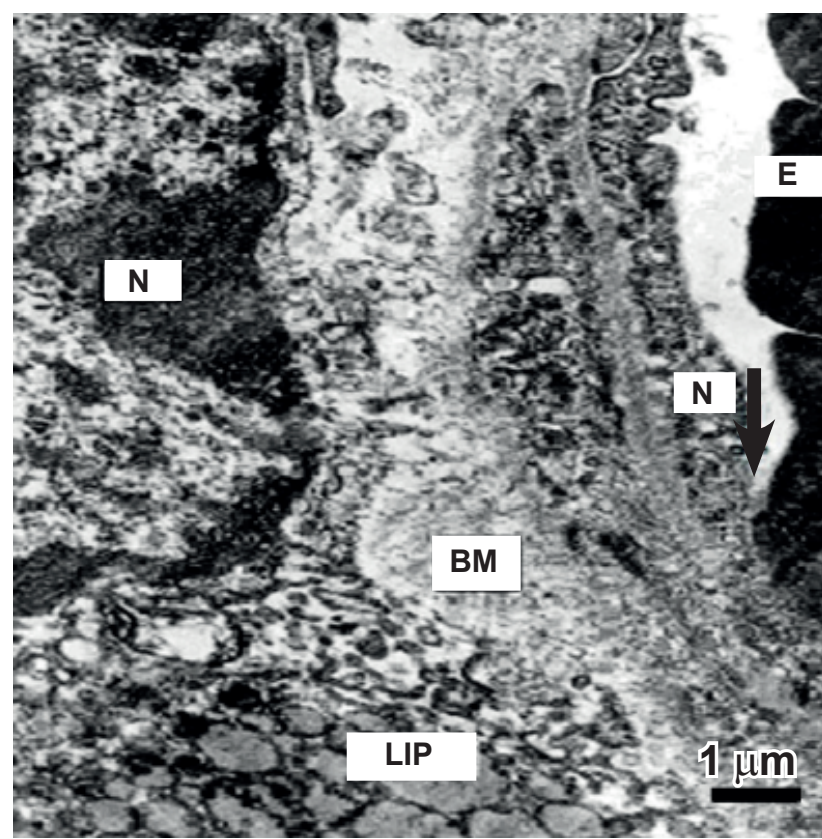

Рис. 3. Мікрофотографрія церебрального капіляра шару III СМД кори головного мозку білого щура контрольної групи 2 на 4-ту добу після моделювання ГФЦІ. Адгезія еритроцитів до поверхні ЕК (стрілка); LIP - ліпіди; E еритроцит; ЕС - ендотеліальна клітина; ВМ - базальна мембрана; $\mathrm{N}$ - ядро перицита.

Fig. 3. Microphoto of capillaries of third layer of the cortex SMA of control group 2 white rat on day 4 after modeling $\mathrm{AFCl}$. Adhesion of red blood cells to EC surface (black arrow); LIP - lipids; E - erythrocyte; EC - endothelial cell; $\mathrm{BM}$ - basement membrane; $\mathrm{N}$ - nucleus of pericyte.

до активації фактора Хагемана, зміни заряду i дзета-потенціалу [4].

Деструктивні зміни в церебральних капілярах поєднуються 3 потужною стимуляцією непошкоджених ЕК, в результаті збільшується продукція як вазорелаксантів, так і вазоконстрикторів. Збільшення судинної проникності церебральних капілярів супроводжується реорганізацією цитоскелета та контактів ЕК із подальшим лізисом і відшаруванням ендотелію від БМ [7].

Аналіз структурних змін СМД кори мозку щурів із ГФЦІ виявив, що за умов нормалізації компонентів, які забезпечують гомеостаз, включаючи стан судинної стінки та мембрано-рецепторний комплекс клітин, можливо мінімізувати наслідки перенесеної катастрофи.

Результати дослідження показали, що на 7-му добу після введення щурам із модельованою ГФЦІ препарату КСКК площа периваскулярного набряку зменшилася на $21,4 \%$, тоді як у тварин групи 2 - всього на $12,7 \%$. При цьому у тварин групи 3 у ті ж самі терміни після моделювання ГФЦІ спостерігався регрес набухання ЕК. Дещо подібні зміни відзначалися у тварин групи 2, але вони були значно менше виражені порівня- with reorganization of cytoskeleton and the contacts of ECs with following lysis and detachment of the endothelium from BM [8].

An analysis of structural changes in SMA of cerebral cortex of rats with AFCI revealed that if the providing homeostasis components are normalized, including the condition of vascular wall and membrane-receptor complex of cells, it is possible to minimize the effects of this catastrophe.

The findings have shown that on day 7 after the rats with the simulated AFCI were administered with the CCBS the area of perivascular edema decreased by $21.4 \%$, whereas for the animals of group 2 that was only by $12.7 \%$. At the same time in the animals of group 3 in the same terms after modeling AFCI the regression of ECs swelling was observed. Some similar changes were found for the animals of group 2, but they were significantly less pronounced if compared to the rats in group 3 treated with the CCBS (Table).

Morphometric analysis of perivascular and pericellular spaces of the third layer of SMA of cerebral cortex on day 7 after modeling AFCI has shown a significant difference in the mean values of their areas. The Table shows that the average area of perivascular spaces, which is an index of vasogenic edema, in rats of group 2 was 45 times higher than that in group 1, but in rats of group 3 treated with CCBS, it was 37 times higher. The average area of pericellular spaces indicating the degree of cytotoxic edema in animals of group 2 on day 7 after AFCI was almost 23 times higher than in group 1 . In rats of group 3 if compared with group 2 this index was increased by 20 times.

Similar changes were also found for the ECs surface area in the AFCI zone. By day 7 of the experiment in the animals of control group 2, the surface area of ECs was $(1,483 \pm 26.48) \mu \mathrm{m}^{2}$, which was significantly bigger than that in the rats of groups 1 and 3 , by 54.1 and $31.6 \%$, respectively (Table). Reduced surface area of ECs after the CCBS introduction may indicate its positive anti-inflammatory effect.

On day 7 of experiment in the rats of group 3 there was a tendency to a rise in the density of cerebral capillaries if compared with intact animals and the animals of group 2 (Table). That is, the treatment of AFCI-simulated animals with the CCBS to some extent stimulated the restoration of ultrastructure of damaged capillaries, increase of their density, as well as the formation of new capillaries. The established changes were confirmed by optical microscopy (Fig. 6). This was especially the case with capillaries that contained $\mathrm{BM}$ with pericyte feet. A new layer of endothelium gradually replacing the lost ECs was appeared on this carcass. 
но зі щурами групи 3, які отримували препарат КСКК (таблиця).

Морфометричний аналіз периваскулярних i перицелюлярних просторів III шару СМД кори головного мозку щурів на 7-му добу після моделювання ГФЦІ показав істотну різницю середніх значень їх площ. 3 таблиці видно, що середня площа периваскулярних просторів, яка $є$ показником вазогенного набряку, в щурів групи 2 у 45 разів перевищувала таку в групі 1, однак у щурів групи 3, що отримували КСКК, вона була більшою у 37 разів. Середня площа перицелюлярних просторів, що вказує на ступінь цитотоксичного набряку, у тварин групи 2 на 7-му добу після ГФЦ майже в 23 рази була більше порівняно з групою 1. У щурів групи 3 порівняно 3 групою 2 даний показник був збільшений у 20 разів.

Подібні зміни стосувалися також площі поверхні ЕК у зоні ГФЦІ. На 7-му добу експерименту у тварин контрольної групи 2 площа поверхні ендотеліоцитів становила (1483 $\pm 26,48)$ мкм $^{2}$, що значуще більше, ніж у щурів груп 1 i 3, на 54,1 та 31,6\% відповідно (таблиця). Зменшення площі поверхні ЕК після введення препарату КСКК може свідчити про його позитивний протизапальний ефект.

На 7-му добу експерименту у щурів групи 3 спостерігалася тенденція до збільшення щільності церебральних капілярів порівняно 3 інтактними тваринами та тваринами групи 2 (таблиця). Тобто лікування щурів із модельованою ГФЦІ препаратом КСКК деякою мірою стимулювало відновлення ультраструктури пошкоджених капілярів, збільшення їх щільності, а також утворення нових капілярів. Встановлені зміни підтверджено за допомогою оптичної мікроскопії (рис. 6). Особливо це було характерно для капілярів, в яких зберігалася БМ із ніжками перицитів. На даному каркасі поступово 3'являвся новий шар ендотелію, що заміщував утрачені ЕК.

Крім того, після використання препарату КСКК зменшувалися, або навіть зникали такі ознаки виснаження репаративної здатності, як звуження робочого просвіту судин, накопичення залишкових тілець у цитоплазмі ЕК, проліферація периваскулярної астроглії i накопичення в ній ліпідів, вторинних лізосом i фібрлярних структур, атрофія ЕК. У цілому ультраструктура судинної стінки виглядала більш збереженою, а пошкодження БМ були менш глибокими.

У зразках тканин головного мозку тварин групи 3 виявлялися новоутворені судини, периваскулярний простір яких відповідав нормаль-

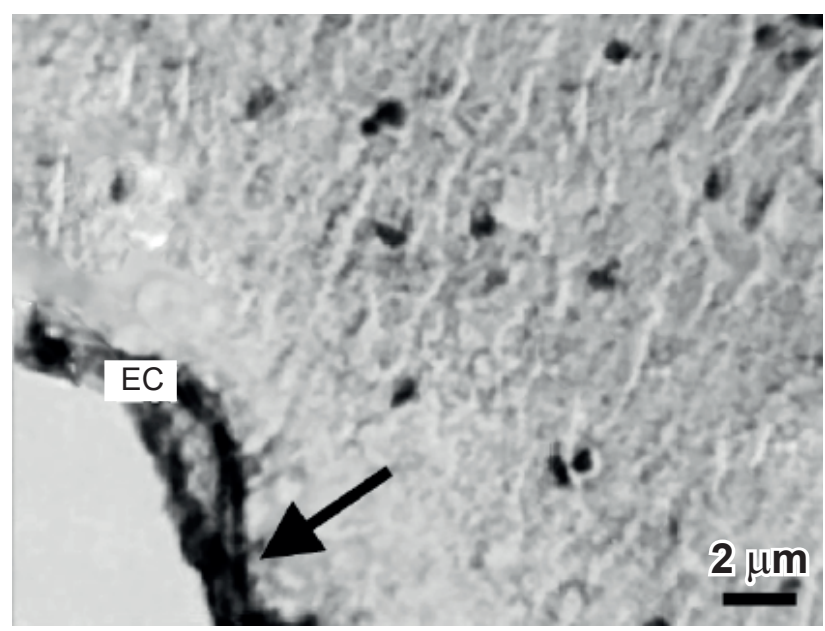

Рис. 4. Мікрофотографрія церебрального капіляра шару III СМД кори головного мозку білого щура групи 3 на 7-му добу після моделювання ГФЦІ. Зона периваскулярного набряку (чорна стрілка); ЕС - ендотеліальна клітина. Забарвлення за Ніслем.

Fig. 4. Microphoto of capillaries of the third layer of the cortex SMA of group 3 white rat on day 7 after modeling $\mathrm{AFCl}$. Zone of perivascular edema (black arrow); EC is an endothelial cell. Nissl staining.

In addition, after the use of the CCBS these signs of depletion of reparative capabilities, such as narrowing of the functioning lumen of vessels, accumulation of residual bodies in ECs cytoplasm, proliferation of perivascular astroglia and accumulation of lipids in it, secondary lyposomes and lysopharyngeal lysosomes decreased or even disappeared. In general, the ultrastructure of vascular wall appeared to be more preserved, and the BM lesions were less profound.

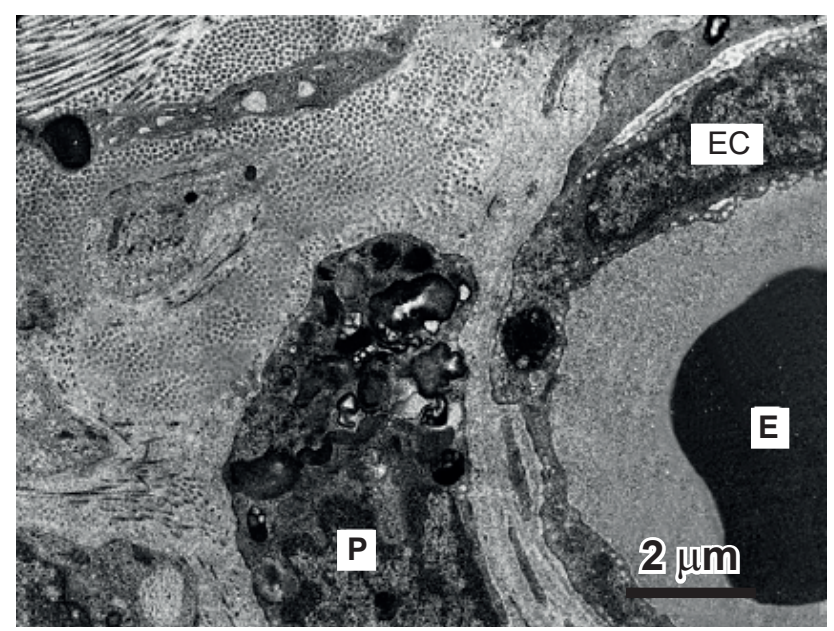

Рис. 5. Мікрофротографрія церебрального капіляра шару III СМД кори головного мозку білого щура групи 3 на 7-му добу після моделювання ГФЦІ. ЕС - ендотеліальна клітина; Е - еритроцит; Р - перицит.

Fig. 5. Microphoto of capillaries of the third layer of the cortex SMA of group 3 white rat on day 7 after modeling $\mathrm{AFCl}$. EC - endothelial cell; $\mathrm{E}$ - erythrocyte; $\mathrm{P}$ - pericyte. 

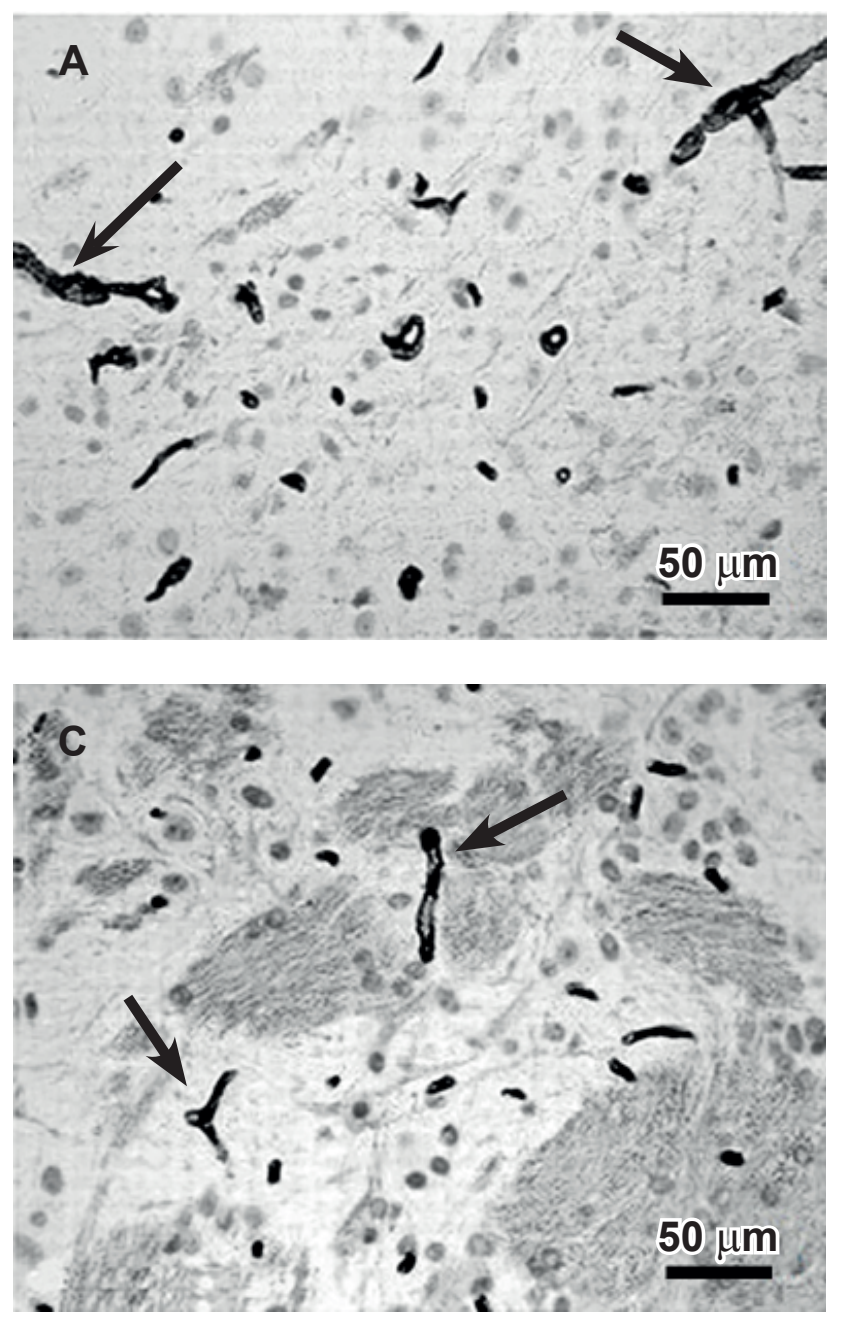

ному. Просвіт судин був прозорим і заповненим плазмою.

За умов гострої гіпоксії, окрім судинної церебральної сітки, відмічалося ураження основної структурної одиниці нервової системи - нейрона. Так, було виявлене збільшення кількості пошкоджених нейронів із різним ступенем дистрофії до незворотних змін. Кількість нормальних нейронів зменшилася на $46,8 \%$. У пошкоджених нейронах спостерігалися різного ступеня вираженості хроматоліз і вакуолізація цитоплазми. Деякі клітини містили пікноморфні ядра. У необоротно пошкоджених нейронах клітинне тіло частково або повністю було зруйноване, фіксувався лізис ядер (рис. 7). У результаті в 4,57 рази підвищувався індекс альтерації (таблиця).

Окрім вищеописаних морфологічних змін нейронів, збільшувалася частота попарного розташування гліальних клітин навколо них, що є непрямою ознакою гіпоксії. Це приводило до збільшення перинейронального сателітного індексу в 3,62 рази (таблиця).

Посилення сателітозу та збільшення перинейронального сателітного індексу свідчать про ви-

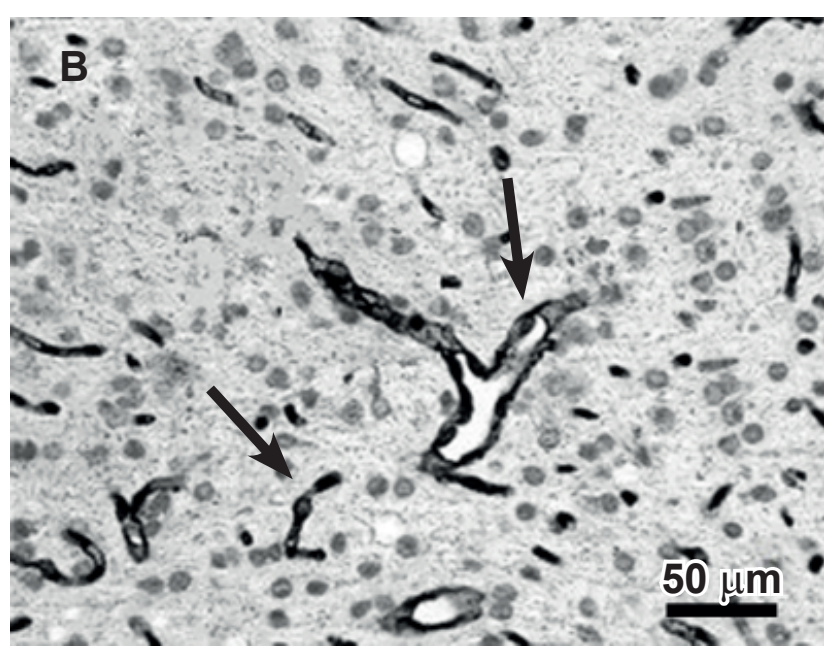

Рис. 6. Мікрофротографрія III шару СМД кори головного мозку білого щура групи 2 на 7-му добу після ГФЦІ (А), дослідної групи 3 із включенням до схеми лікування КСКК (B) та групи 1 (C). Церебральні капіляри - чорна стрілка; забарвлення гематоксиліном і еозином.

Fig. 6. Microphoto of the third layer of the cortex SMA of group 2 white rat on day 7 after $\mathrm{AFCl}(\mathbf{A})$, experimental group 3 with the inclusion into the treatment protocol of CCBS (B) and group 1 (C). Cerebral capillaries - black arrow; hematoxylin and eosin staining.

In samples of brain tissues of animals in group 3 thenewly formed vessels were found, the perivascular space of which corresponded to normal. The lumen of vessels was transparent and filled with plasma.

In acute hypoxia, besides cerebral vascular network, there was a lesion of basic structural unit of the nervous system, $i$. e. neuron. Thus, an increased number of injured neurons with varying degrees of dystrophy was found to be irreversible. The number of normal neurons was decreased by $46.8 \%$. In damaged neurons the cytoplasm chromatolysis and vacuolation were observed. Some cells contained pycnomorphic nuclei. In irreversibly damaged neurons, the cell body was partially or completely destroyed, and the lysis of the nuclei was observed (Fig. 7). As a result, the index of alteration (Table) was 4.57 times increased.

In addition to morphological changes in neurons described above, the frequency of paired glial cells around them increased, which is an indirect sign of hypoxia. This led to a rise in perineuronal satellite index in 3.62 times (Table).

Enhanced satellitosis and increased perineuronal satellite index indicate a high level of neuronal functional stress, in which their energy reserves are lost and their neuroplastic capacity is critically reduced. No signs of brain tissue gliosis were found, that is explained by short periods of ob- 
сокий рівень функціонального напруження нейронів, при якому втрачаються їх енергетичні запаси і критично знижуються нейропластичні можливості. Ознак гліозу тканини мозку виявлено не було, що пояснюється короткими термінами спостереження в найгострішому періоді ГФЦ. У результаті гліонейрональний індекс, що визначається як співвідношення кількості клітин нейроглії до кількості нейронів, не змінювався (таблиця).

Отримані дані свідчать про те, що за умов експериментальної ГФЦ уражуються як клітини, так і судини нервової системи, що й обумовлює складну неврологічну симптоматику ІГМ.

Ми вважаємо, що виявлені в ході експерименту зміни стану судинної церебральної сітки, нейронів та клітин глії є адаптативно-пристосувальними механізмами при ГФЦІ, що запускається одразу після припинення церебрального кровотоку. Гостра гіпоксія є потужним стимулятором компенсаторного нейро- й ангіогенезу, який значно впливає на посилення нейропластичності мозкової тканини та визначає перебіг захворювання. Але описані механізми не здатні повною мірою впливати на реактивні порушення в тканині мозку, що розгортаються в перші хвилини гострої гіпоксії.

На жаль, сучасні можливості стимуляції компенсаторних реакцій та активації процесів ней-

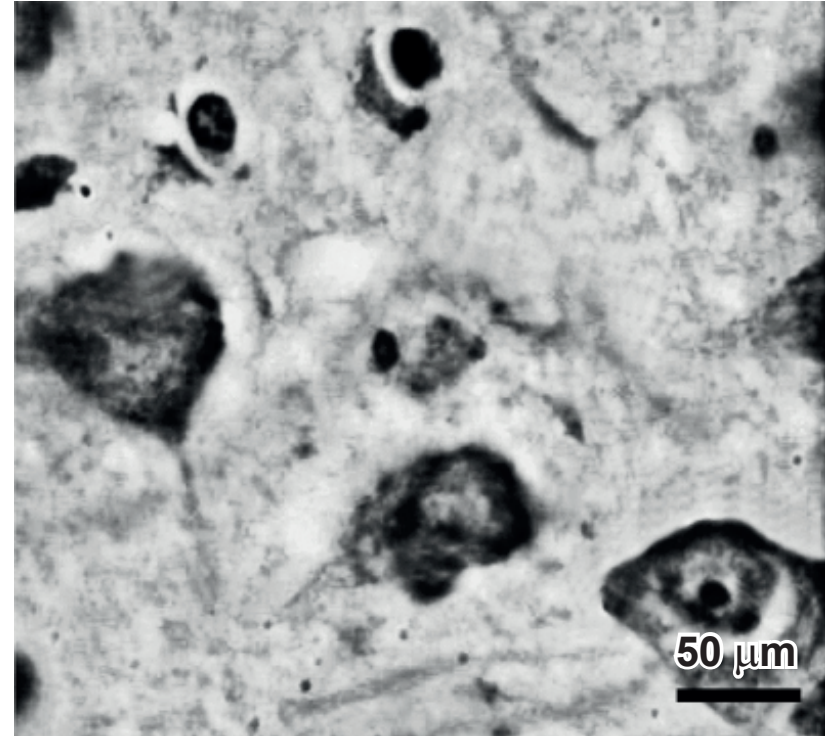

Рис. 7. Мікрофротографрія нейронів III шару СМД кори головного мозку білого щура контрольної групи 2 на 4-ту добу після ГФЦІ. Забарвлення гематоксиліном і еозином.

Fig. 7. Microphoto of neurons of the third layer of the cortex SMA of control group 2 white rat on day 4 after AFCl. Hematoxylin and eosin staining.

servation in the most acute period of AFCI. As a result, the glioneuronal index, defined as the ratio of the number of neuroglia cells to the one of neurons, did not change (Table).

Вплив КСКК на морфологічні показники III шару СМД кори мозку щурів на 7-му добу після моделювання ГФЦІ Influence of CCBS on morphological indices of the third layer of cortex SMA on day 7 after simulation AFCl

\begin{tabular}{|c|c|c|c|}
\hline \multirow{2}{*}{$\begin{array}{l}\text { Показники } \\
\text { Indices }\end{array}$} & \multicolumn{3}{|c|}{$\begin{array}{l}\text { Група тварин } \\
\text { Group of animals }\end{array}$} \\
\hline & 1 & 2 & 3 \\
\hline $\begin{array}{c}\text { Площа периваскулярних просторів, мкм }{ }^{2} \\
\text { Area of perivascular spaces, } \mu \mathrm{m}^{2}\end{array}$ & $3 \pm 0,98$ & $134 \pm 1,23 *$ & $112 \pm 1,41^{* \#}$ \\
\hline $\begin{array}{c}\text { Площа перицелюлярних просторів, мкм² } \\
\text { Area of pericellular spaces, } \mu \mathrm{m}^{2}\end{array}$ & $4 \pm 0,74$ & $92 \pm 2,08^{*}$ & $81 \pm 1,84$ \\
\hline $\begin{array}{l}\text { Площа поверхні ендотеліальних клітин, мкм² } \\
\text { Area of surface of endothelial cells, } \mu \mathrm{m}^{2}\end{array}$ & $962 \pm 21,35$ & $1483 \pm 26,48 *$ & $1127 \pm 30,14^{\#}$ \\
\hline $\begin{array}{l}\text { Щільність церебральних капілярів, мм³ } \\
\text { Density of cerebral capillaries, } \mathrm{mm}^{3}\end{array}$ & $2534 \pm 36,74$ & $2719 \pm 29,87$ & $3087 \pm 41,38$ \\
\hline $\begin{array}{l}\text { Індекс альтерації } \\
\text { Alteration index }\end{array}$ & $0,0326 \pm 0,002$ & $0,148 \pm 0,003^{*}$ & $0,123 \pm 0,002$ \\
\hline $\begin{array}{l}\text { Перинейрональний індекс } \\
\text { Perineuronal index }\end{array}$ & $1,486 \pm 0,027$ & $5,379 \pm 0,107^{*}$ & $4,624 \pm 0,092$ \\
\hline $\begin{array}{l}\text { Гліонейрональний індекс } \\
\text { Glioneuronal index }\end{array}$ & $0,623 \pm 0,12$ & $0,782 \pm 0,16$ & $0,763 \pm 0,11$ \\
\hline $\begin{array}{l}\text { Нормальні нейрони, од./мкм }{ }^{2} \\
\text { Normal neurons, unit/ } \mu \mathrm{m}^{2}\end{array}$ & $91,34 \pm 1,252$ & $48,59 \pm 2,158 *$ & $56,24 \pm 1,252$ \\
\hline $\begin{array}{l}\text { Пошкоджені нейрони, од./мкм² } \\
\text { Injured neurons, unit } / \mu \mathrm{m}^{2}\end{array}$ & $2,48 \pm 0,144$ & $33,45 \pm 1,674^{*}$ & $26,24 \pm 1,214^{\#}$ \\
\hline
\end{tabular}

Примітки: * - відмінності статистично значущі відносно групи 1 ( $<<0,05)$; ${ }^{\text {- }}$ відмінності статистично значущі відносно групи $2(p<0,05)$.

Notes: * - differences were statistically significant with respect to group $1(p<0.05)$; ${ }^{\#}$ - differences were statistically significant with respect to group $2(p<0.05)$. 
рорегенерації є вкрай обмеженими. Основними механізмами нейропластичності за умов будьяких церебральних катастроф вважаються явища за типом sprouting (посилення розгалуження відростків нейронів від вже існуючих), non-sprouting (розширення, розщеплення, злиття існуючих відростків), утворення нових синапсів, зміни мембранного потенціалу та запуск вторинного ангіогенезу.

На нашу думку, однією із можливих причин вказаних змін може бути активація репаративних процесів у тканині мозку за участі ряду біологічно активних речовин, що містяться в складі препарату КСКК, оскільки після його введення у тварин із ГФЦІ відбувається більш активна стимуляція механізмів відновлення тканини мозку порівняно 3 контрольними. Ймовірно, це відбувається за рахунок впливу на процеси нейро- та ангіогенезу при ГФЦІ факторів росту специфічних трофічних регулюючих речовин пептидної природи, що можуть стимулювати мітогенез, хемотаксис, диференціювання клітин і ангіогенез $[13,27]$. При цьому основним механізмом регуляції процесів ангіогенезу $є$ активація проліферації ендотеліоцитів, що приводить до ремоделювання існуючих судин і утворення нових [12].

Результати проведеного дослідження вказують на стимулюючий вплив КСКК на процеси ангіогенезу в ішемізованій тканині мозку, про який свідчать швидке відновлення ультраструктури пошкоджених капілярів та утворення нових. При цьому стимуляторами ангіогенезу можуть бути васкулоендотеліальний фактор росту, фактор росту фібробластів, тромбоцитарний фактор росту, трансформуючі фактори росту $\beta$, інсуліноподібний фактор росту 1 , які в значній кількості присутні в кордовій крові $[20,25]$. Однозначно, процеси ангіо- та нейрогенезу $\epsilon$ взаємопов'язаними. Більшість присутніх у КСКК факторів росту, що стимулюють ангіогенез, також безпосередньо впливають і на процеси утворення нових нейронів [23].

Стимулюванню ангіо- та нейрогенезу може також сприяти протизапальна дія КСКК, що реалізується завдяки присутності в препараті протизапальних цитокінів - інтерлейкінів-4, 8, 10 (ІЛ-4, ІЛ-8, ІЛ-10) $[15,22]$ та трансформуючого фактору росту $\beta$ [21]. Слід зазначити, що ІЛ-8 $\epsilon$ не тільки протизапальним агентом, а й промоутором ангіогенної активності, стимулюючи виживання, проліферацію та міграцію ЕК [24].

Екзосоми сироватки кордової крові, які містять мікроРНК, також можуть активувати проліферацію та міграцію ендотеліоцитів людини 3
The findings indicate that under experimental AFCI both cells and vessels of nervous system are affected, that causes complicated neurological symptoms of the IS.

It is supposed that the changes in a state of cerebral vascular network, neurons, and glial cells detected during the experiment are the adaptive mechanisms during AFCI, which are triggered immediately after the cerebral blood flow is stopped. Acute hypoxia is a potent stimulator of compensatory neuro- and angiogenesis, which significantly affects the enhancement of brain tissue neuroplasticity and determines the disease course. However the described mechanisms are not able to fully influence the reactive disorders in brain tissue, which develop in the first minutes of acute hypoxia.

Unfortunately, current possibilities of stimulation of compensatory responses and activation of neuroregeneration are extremely limited. The main mechanisms of neuroplasticity under conditions of any cerebral catastrophes are the phenomena such as sprouting (enhancement of branching of neuronal processes from existing ones), non-sprouting (expansion, splitting, fusion of existing processes), formation of new synapses, change of membrane potential and triggering of secondary angiogenesis.

We believe that one of possible reasons for these changes may be the activation of reparative processes in brain tissue with the involvement of a number of biologically active substances contained in the CCBS, since after its introduction to the animals with AFCI the more active stimulation of the mechanisms of brain tissue repair compared to the control occurs. This is likely due to the influence of growth factors, specific trophic regulators of peptide nature, on the neuro- and angiogenesis processes in AFCI, which can stimulate mitogenesis, chemotaxis, cell differentiation and angiogenesis [7, 27]. The main mechanism, regulating an angiogenesis, is an activation of ECs proliferation, which leads to remodeling of existing vessels and formation of new ones [6].

The research results point out a stimulating effect of CCBS on angiogenesis in ischemic brain tissue, as evidenced by a rapid restoration of ultrastructure of damaged capillaries and formation of new ones. In this case, vascular endothelial growth factor, fibroblast growth factor, platelet growth factor, transforming growth factors $\beta$, insulin-like growth factor 1 , being largely present in cord blood can stimulate angiogenesis $[15,21]$. Definitely, the processes of angio- and neurogenesis are interrelated. Most of the angiogenesis-stimulating growth 
наступним утворенням капілярів, на що вказують результати дослідження L. Jia та співавт. [18].

Крім цього, фактори, які містяться в плазмі кордової крові, можуть чинити антиапоптичну та нейропротекторну дію [16] на клітини мозку, які знаходяться в зоні пошкодження, збільшуючи вірогідність їх виживання [25].

Таким чином, результати проведеного дослідження вказують на те, що КСКК може бути ефективним препаратом для лікування пошкоджень мозкової тканини, які спричинені гострою фокальною церебральною ішемією.

\section{Висновки}

1. Експериментальне порушення церебрального кровообігу викликає потужний нейротоксичний ефект, який характеризується різного ступеня розладами структурно-функціонального стану нейронів і клітин нейроглії головного мозку щурів, що підтверджується такими якісними і кількісними показниками, як альтераційний (збільшення у 4,57 рази по відношенню до групи 1) і перинейрональний сателітний (підвищення у 3,62 рази по відношенню до групи 1) індекси.

2. Дистрофічні зміни нейронів, формування нейронодегенеративних процесів в умовах експериментальної ГФЦ відбуваються на тлі мікроциркуляторних порушень, i можуть бути пов'язані 3 набряком мозкової тканини (середня площа периваскулярних просторів у щурів групи 2 у 45 разів перевищувала таку в тканині мозку інтактних тварин) і вторинним спазмом судин, які призводять до подальшого порушення трофіки нейронів внаслідок зменшення надходження кисню та поживних речовин у клітини.

3. На моделі експериментальної ГФЦ з введенням КСКК було встановлено, що даний імунобіологічний препарат проявляє виражені нейро- й ангіопротекторні властивості, активує репаративні процеси в перинекротичній зоні за рахунок підвищення на 7-му добу щільності капілярів на 21,8\% порівняно 3 інтактними тваринами й збільшення площі поверхні капілярного русла, попереджає розвиток неминучої дисфункції гематоенцефалічного бар'єра та мембрано-рецепторного комплексу нейронів і клітин нейроглії в динаміці захворювання.

\section{Література}

1. Буданцев АЮ, редактор. Стереотаксический атлас мозга крысы (фронтальные сечения). Пущино: Аналитическая микроскопия; 2002. с. 7-15. factors present in CCBS also directly affect the formation of new neurons [19].

Stimulation of angio- and neurogenesis can also be facilitated by an anti-inflammatory effect of CCBS, which is implemented via the presence in the product of anti-inflammatory cytokines - interleukins-4, 8, 10 (IL-4, IL-8, IL-10) [10, 18] and transforming growth factor $\beta$. It should be noted that IL-8 is not only an anti-inflammatory agent but also a promoter of angiogenic activity, stimulating EC survival, proliferation and migration [20].

The cord blood exosomes, containing microRNA, can also activate proliferation and migration of human ECs with subsequent capillary formation, as indicated by the results of L. Jia et al. [13].

In addition, the factors contained in cord blood plasma can exert anti-apoptotic and neuroprotective effects [11] on brain cells being in the lesion area, increasing probability of their survival [21].

Thus, the results of this study indicate that the CCBS can be an effective agent to treat a brain tissue injury caused by AFCI.

\section{Conclusions}

1. Impaired cerebral circulation in experiment causes a strong neurotoxic effect, characterized by varying degrees of structural and functional impairment of neurons and cells of neuroglia, which confirmed by such qualita tive and quantitative indices as the alteration (4.57-fold increase versus group 1) and perineuronal satellite (3.62-fold increase versus group 1) indices.

2. Dystrophic changes in neurons, formation of neurodegenerative processes in experimental AFCI occurred on the basis of microcirculatory disorders, and might be associated with brain tissue edema (the average area of perivascular spaces in rats of group 2 was in 45 times higher than that of intact brain tissue), secondary vasospasm that led to further disruption of neuronal trophism because of a decreased supply of oxygen and nutrients to the cells.

3. In the model of experimental AFCI with the CCBS introduction, it was found that this immunobiological product exhibited a pronounced neuro- and angioprotective properties, activated reparation in perinecrotic zone due to an increase on day 7 of the capillary density by $21.8 \%$ if compared with the intact animals and rise in the capillary bed surface area, prevented the development of inevitable dysfunction of the blood-brain barrier and membrane-receptor complex of neurons and neuroglia cells in the disease dynamics. 
2. Введенский БП, Ковалев ГА, Тыныныка ЛН, и др. Криоконсервированная сыворотка кордовой крови при лечении деструктивно-дистрофических процессов в суставах. Вестник неотложной и восстановительной медицины. 2012; 13(1): 41-3.

3. Колесник ВВ. Експериментальний тромбоемболічний інсульт у щурів лінії Вістар як варіант патофізіологічної модел гострих порушень мікроциркуляції за ішемічним типом. Патологія. 2011; (1): 56-9.

4. Мізюк ВМ. Ендотеліальна дисфункція та шляхи її корекції у хворих на артеріальну гіпертензію із супутньою серцевою недостатністю. Буковинський медичний вісник. 2014; 18(2): 66-8.

5. Стефранов ОВ, редактор. Доклінічні дослідження лікарських засобів. Методичні рекомендації. Київ: Авіцена; 2001. 528 с.

6. Трифонов ВЮ, Прокопюк ВЮ, Зайченко АВ. Криоконсервированная сыворотка кордовой крови в восстановлении репродуктивной функции при антифосфолипидном синдроме. Проблемы криобиологии. 2011; 21 (1): 75-84.

7. Черний ВИ, Колесников АН, Городник ГА, и др. Оценка риска возникновения тромбоэмболических осложнений и эффективность различных методов профилактики у пациентов в критическом состоянии. Практична ангіологія. 2008; 7-8: 59-65.

8. Adini A, Adini I, Ghosh K, et al. The stem cell marker prominin-1/ CD133 interacts with vascular endothelial growth factor and potentiates its action. Angiogenesis. 2013; 16 (2): 405-16.

9. Benjamin EJ, Blaha MJ, Chiuve SE, et al. Heart disease and stroke statistics - 2017 update: a report from the American Heart Association. Circulation. [Internet] 2017; 135(10): [cited 2017 Jan 25]. e146-e603. Available from: https://www.ahajournals. org/doi/pdf/10.1161/CIR.0000000000000485.

10.Bok S, Kim YE, Woo Y. Hypoxia-inducible factor-1a regulates microglial functions affecting neuronal survival in the acute phase of ischemic stroke in mice. Oncotarget. 2017; 8 (67): 111508-521.

11. Brandao D, Costa C, Canedo A, et al. Endogenous vascular endothelial growth factor and angiopoietin-2 expression in critical limb ischemia. Int Angiol. 2011; 30 (1): 25-34.

12.Buzzia M, Versurab P, Grigoloc B, et al. Comparison of growth factor and interleukin content of adult peripheral blood and cord blood serum eye drops for cornea and ocular surface diseases. Transfus Apher Sci. 2018; 57: 549-55.

13. Castellano JM, Mosher KI, Abbey RJ, et al. Human umbilical cord plasma proteins revitalize hippocampal function in aged mice. Nature. 2017; 544(7651): 488-92.

14.Dávalos A, Avarez-Sabín J, Castillo J, et al. Citicoline in the treatment of acute ischaemic stroke: an international, randomised, multicentre, placebo-controlled study (ICTUS trial). Lancet. 2012; 380(9839): 349-57.

15.Ehrhart J, Sanberg PR, Garbuzova-Davis S. Plasma derived from human umbilical cord blood: Potential cell-additive or cellsubstitute therapeutic for neurodegenerative diseases. J Cell Mol Med. 2018; 22: 6157-66.

16.Eve DJ, Ehrhart J, Zesiewicz T, et al. Plasma derived from human umbilical cord blood modulates mitogen-induced proliferation of mononuclear cells isolated from the peripheral blood of ALS patients. Cell Transplant. 2016; 25: 963-71.

17.Fu FW, Rao J, Zheng YY. Ischemic stroke in patients with POEMS syndrome: a case report and comprehensive analysis of literature. Oncotarget. 2017; 8 (51): 89406-24.

18.Jia L, Zhou X, Huang X, et al. Maternal and umbilical cord serum- derived exosomes enhance endothelial cell proliferation and migration. FASEB J. 2018; 32(8): 4534-43.

19.Katsimpardi L, Litterman NK, Schein PA, et al. Vascular and neurogenic rejuvenation of the aging mouse brain by young systemic factors. Science. 2014; 344(6184), 630-34.

20.Kim Y-M, Jung M-H, Song H-Y, et al. Ex vivo expansion of human umbilical cord blood-derived T-lymphocytes with homologous cord blood plasma. Tohoku J Exp Med. 2005; 205: 115-22.

\section{References}

1. Adini A, Adini I, Ghosh K, et al. The stem cell marker prominin-1/ CD133 interacts with vascular endothelial growth factor and potentiates its action. Angiogenesis. 2013; 16 (2): 405-16.

2. Benjamin EJ, Blaha MJ, Chiuve SE, et al. Heart disease and stroke statistics - 2017 update: a report from the American Heart Association. Circulation. [Internet] 2017; 135(10): [cited 2017 Jan 25]. e146-e603. Available from: https://www.ahajournals. org/doi/pdf/10.1161/CIR.0000000000000485.

3. Bok S, Kim YE, Woo Y. Hypoxia-inducible factor-1a regulates microglial functions affecting neuronal survival in the acute phase of ischemic stroke in mice. Oncotarget. 2017; 8 (67): 111508- 21.

4. Brandao D, Costa C, Canedo A, et al. Endogenous vascular endothelial growth factor and angiopoietin-2 expression in critical limb ischemia. Int. Angiol. 2011; 30 (1): 25-34.

5. Budantsev AYu, Editor. [Stereotaxic atlas of the rat brain (frontal sections)]. Pushchino: Analiticheskaya mikroskopiya; 2002. p. 7-15. Russian.

6. Buzzia M, Versurab P, Grigoloc B, et al. Comparison of growth factor and interleukin content of adult peripheral blood and cord blood serum eye drops for cornea and ocular surface diseases. Transfus Apher Sci. 2018; 57: 549-55.

7. Castellano JM, Mosher KI, Abbey RJ, et al. Human umbilical cord plasma proteins revitalize hippocampal function in aged mice. Nature. 2017; 544(7651): 488-92.

8. Chernii VI, Kolesnikov AN, Gorodnik GA., et al. [Assessment of the risk of thromboembolic complications and the effectiveness of various prevention methods in patients in critical condition.] Praktichna angiologiya. 2008; 7-8: 59-65. Russian.

9. Dávalos A, Avarez-Sabín J, Castillo J, et al. Citicoline in the treatment of acute ischaemic stroke: an international, randomised, multicentre, placebo-controlled study (ICTUS trial). Lancet. 2012; 380(9839): 349-57.

10.Ehrhart J, Sanberg PR, Garbuzova-Davis S. Plasma derived from human umbilical cord blood: Potential cell-additive or cellsubstitute therapeutic for neurodegenerative diseases. J Cell Mol Med. 2018; 22: 6157-66.

11. Eve DJ, Ehrhart J, Zesiewicz T, et al. Plasma derived from human umbilical cord blood modulates mitogen-induced proliferation of mononuclear cells isolated from the peripheral blood of ALS patients. Cell Transplant. 2016; 25: 963-71.

12.Fu FW, Rao J, Zheng YY. Ischemic stroke in patients with POEMS syndrome: a case report and comprehensive analysis of literature. Oncotarget. 2017; 8 (51): 89406-24.

13.Jia L, Zhou X, Huang $X$, et al. Maternal and umbilical cord serum- derived exosomes enhance endothelial cell proliferation and migration. FASEB J. 2018; 32(8): 4534-43.

14.Katsimpardi L, Litterman NK, Schein PA, et al. Vascular and neurogenic rejuvenation of the aging mouse brain by young systemic factors. Science. 2014; 344(6184), 630-4.

15. Kim Y-M, Jung $M-H$, Song $H-Y$, et al. Ex vivo expansion of human umbilical cord blood-derived T-lymphocytes with homologous cord blood plasma. Tohoku J Exp Med. 2005; 205: 115-22.

16. Kolesnik VV. Experimental thromboembolic stroke in Wistar rats as an alternative pathophysiological model of acute disorders of microcirculation in ischemic type. Pathologia. 2011; 8(1): 56-9. Russian.

17. Lam AC, Li K, Zhang XB, et al. Preclinical ex vivo expansion of cord blood hematopoietic stem and progenitor cells: duration of culture; the media, serum supplements, and growth factors used; and engraftment in NOD/SCID mice. Transfusion. 2001; 41: 1567-76.

18. Li M, Zhang Y, Feurino LW, et al. Interleukin-8 increases vascular endothelial growth factor and neuropilin expression and stimulates ERK activation in human pancreatic cancer. Cancer Sci. 2008; 99: 733-7.

19.Lin W, Hsuan Y, Lin M, et al. Human umbilical cord mesenchymal stem cells preserve adult newborn neurons and reduce neurological injury after cerebral ischemia by reducing 
21.Lam AC, Li K, Zhang XB, et al. Preclinical ex vivo expansion of cord blood hematopoietic stem and progenitor cells: duration of culture; the media, serum supplements, and growth factors used; and engraftment in NOD/SCID mice. Transfusion. 2001; 41: 1567-76.

22.Li M, Zhang Y, Feurino LW, et al. Interleukin-8 increases vascular endothelial growth factor and neuropilin expression and stimulates ERK activation in human pancreatic cancer Cancer Sci. 2008; 99: 733-7.

23. Lin W, Hsuan Y, Lin M, et al. Human umbilical cord mesenchymal stem cells preserve adult newborn neurons and reduce neurological injury after cerebral ischemia by reducing the number of hypertrophic microglia/macrophages. Cell Transplantation. 2017; 26(11), 1798-810.

24. Martin D, Galisteo R, Gutkind JS. CXCL8/IL8 stimulates vascular endothelial growth factor (VEGF) expression and the autocrine activation of VEGFR2 in endothelial cells by activating NFkappaB through the CBM (Carma3/Bcl10/Malt1) complex. J Biol Chem. 2009; 284: 6038-42.

25. Min K, Song J, Lee JH, et al. Allogenic umbilical cord blood therapy combined with erythropoietin for patients with severe traumatic brain injury: three case reports. Restor Neuro Neurosci. 2013; 31: 397-410.

26. Toshkezi G, Kyle M, Longo SL, et al. Brain repair by hematopoietic growth factors in the subacute phase of traumatic brain injury. J Neurosurg [Internet]. 2018 [cited 2018 Dec 27]. Available from: https://thejns.org/view/journals/j-neurosurg/ 129/5/article-p1286.xml

27. Yoo J, Kim H, Seo J, et al. Therapeutic effects of umbilica cord blood plasma in a rat model of acute ischemic stroke. Oncotarget. 2016; 7(48): 79131-40. the number of hypertrophic microglia/macrophages. Cell Transplantation. 2017; 26(11), 1798-810.

20.Martin D, Galisteo R, Gutkind JS. CXCL8/IL8 stimulates vascular endothelial growth factor (VEGF) expression and the autocrine activation of VEGFR2 in endothelial cells by activating NFkappaB through the CBM (Carma3/Bcl10/Malt1) complex. J Biol Chem. 2009; 284: 6038-42.

21. Min K, Song J, Lee JH, et al. Allogenic umbilical cord blood therapy combined with erythropoietin for patients with severe traumatic brain injury: three case reports. Restor Neurol Neurosci. 2013; 31: 397-410.

22. Miziuk VM. [Endothelial dysfunction and means of its correction in patients with hypertension and concomitant heart failure. Buk.] Med. Herald. 2014; 18(2): 66-8. Ukrainian.

23.Stefanov OV, Editor. [Preclinical studies of drugs. Guidelines.] Kyiv: Avitsenna; 2001. 528 p. Ukrainian.

24. Toshkezi G, Kyle M, Longo SL, et al. Brain repair by hematopoietic growth factors in the subacute phase of traumatic brain injury. J Neurosurg [Internet]. 2018 Jan 26 [cited 2018 Dec 27]. Available from:https://thejns.org/view/journals/j-neurosurg/ 129/5/article-p1286.xml

25.Trifonov VYu, Prokopyuk VYu, Zaychenko AV. Cryopreserved cord blood serum for reproductive function restoration during antiphospholipid syndrome. Problems of Cryobiology. 2011; 21 (1): 75-84

26. Vvedenskiy BP, Kovalev GA, Tynynyka LN, et al. [Cryopreserved cord blood serum in treatment of destructive and dystrophic processes in joints.] Bulletin of Urgent and Recovery Medicine. 2012; 13(1): 41-3. Russian.

27. Yoo J, Kim H, Seo J, et al. Therapeutic effects of umbilical cord blood plasma in a rat model of acute ischemic stroke. Oncotarget. 2016; 7(48): 79131-40. 